\title{
PEMBELAJARAN MATEMATIKA DENGAN PENDEKATAN MATHEMATICS IN CONTEXT PADA KEMAMPUAN DAN KETERAMPILAN BERPIKIR KREATIF
}

\author{
Eka Farida Fasha, S.Si., M.Pd. \\ Prodi Pendidikan Matematika Universitas Peradaban \\ Email: efaridafasha@yahoo.co.id
}

\begin{abstract}
The purpose of this study is to determine the increase of creative thinking ability and creative thinking skill in mathematics learning with mathematic in context approach. The technique analisys used is the average comparative test for pretest and posstest data. To see an increased creative thinking skill, researcher compare the average value of creative thinking skills from the first meeting, the meeting II and III meeting. The result showed that there is an increasing of creative thinking ability and crtative thinking skill in mathematics learning with mathematic in context approach.

Keyword: Mathematic In Context, Creative Thinking Ability and Creative Thinking Skill.
\end{abstract}

Abstrak
Tujuan penelitian ini adalah mengetahui peningkatan kemampuan dan keterampilan
berpikir kreatif pada pembelajaran matematika dengan pendekatan Mathematic In
Context. Teknik analisis yang digunakan yaitu uji banding rata-rata skor pretest dan
posttest. Untuk melihat adanya peningkatan kemampuan berpikir kreatif peneliti
membandingkan rata-rata nilai keterampilan berpikir kreatif dari pertemuan I,
pertemuan II dan pertemuan III. Hasil penelitian menunjukan bahwa ada peningkatan
kemampuan dan keterampilan berpikir kreatif pada pembelajaran matematika dengan
pendekatan Mathematic In Context.
Kata kunci: Mathematic In Context, Kemampuan Berpikir Kretaif, Keterampilan
Berpikir Kreatif.

\section{PENDAHULUAN}

Siswa pada dasarnya kreatif, memiliki kemampuan menggunakan pikiran dan imajinasi mereka secara konstruktif, untuk menghasilkan sesuatu yang baru. Berpikir kreatif dapat dilakukan dengan merumuskan sebuah ide baru yang akan semakin menyempurnakan produk yang sudah ada, atau bisa menciptakan sebuah cara yang benar-benar baru, memperbaiki sesuatu yang sudah 
dikenal maupun memperkenalkan sesuatu yang unik, dapat pula dengan aktualisasi ide orisinil dan kegiatan lainnya yang menunjukkan hal yang baru atau berbeda dari sebelumnya. Menurut Hamalik (2008), pendidikan modern menitik beratkan pada aktivitas, dimana siswa belajar sambil bekerja. Dengan bekerja, siswa memperoleh pemahaman pengetahuan, pemahaman dan ketrampilan. Sehubungan dengan hal tersebut, pembelajaran perlu menekankan pada asas keaktifan siswa dalam proses pembelajaran.

Model pembelajaran yang dipilih sebaiknya menekankan pembelajaran aktif secara mental dengan tujuan untuk meningkatkan kemampuan berpikir kreatif matematika (Pehkonen, 1997). Oleh karena itu perlu dikembangkan pembelajaran dengan model yang melibatkan aktifitas tersebut pada kemampuan berpikir kreatif matematika. Pembelajaran dengan pendekatan Mathematic In Context sesuai dengan penelitian yang dilakukan oleh Chan pada tahun 2005 (Titikusumawati, 2009) ditunjukkan bahwa pembelajaran dengan model diskusi menggunakan pendekatan Mathematic In Context lebih baik dibandingkan dengan yang metode pembelajaran lainnya, Terdapat kesesuaian antara teori discovery dengan Mathematic In Context, penelitian menunjukan klasifikasi dan karakterisasi model matematika, serta definisi tentang "model matematika"; dengan cara yang sama, hal itu menunjukkan keterampilan dan pemikiran kognitif yang mempengaruhi dalam membangun model matematika dalam konteks (Camarena, 2003).

Penelitian serupa dilakukan oleh Tumarang (2000) menunjukkan bahwa pembelajarn melalui pemecahan masalah dapat meningkatkan kemampuan pemahaman konsep pengurangan. Inti pada pembelajaran dengan pendekatan Mathematic In Context adalah siswa dapat belajar matematika dalam kontek apapun, yang menjadikan siswa tidak bosan untuk belajar matematika sehingga motivasi untuk belajar matematika dapat tumbuh. Latar belakang yang telah diuraikan di atas, dapat dirumuskan permasalahan sebagai berikut: Apakah pembelajaran dengan pendekatan Mathematic In Context pada pembelajaran matematika dapat meningkatkan kemampuan berpikir kreatif materi bangun datar.

\section{KAJIAN TEORI \\ Mathematic In Context}

Mathematic In Context terdiri dari tugas-tugas matematika dan pertanyaan yang dirancang untuk merangsang pemikiran matematika dan untuk mempromosikan diskusi di antara siswa. Gravemeijer (2000) menyebutkan tiga prinsip tersebut, yaitu (1) guided reinvention and progressive mathematizing didactical phenomenology dan (3) self-developed models.
1. Guided reinvention and progressive mathematizing. 
Menurut Gravemijer (2000), berdasar prinsip reinvention, para siswa semestinya diberi kesempatan untuk mengalami proses yang sama dengan proses saat matematika ditemukan. Selain itu prinsip reinvention dapat pula dikembangkan berdasar prosedur penyelesaian informal. Dalam hal ini strategi informal dapat dipahami untuk mengantisipasi prosedur penyelesaian formal. Untuk keperluan tersebut maka perlu ditemukan masalah kontekstual yang dapat menyediakan beragam prosedur penyelesaian serta mengindikasikan rute pembelajaran yang berangkat dari tingkat belajar matematika secara nyata ke tingkat belajar matematika secara formal (progressive mathematizing).

2. Didactical phenomenology. Gravemeijer (2000) menyatakan, berdasar prinsip ini penyajian topik-topik matematika yang termuat dalam pembelajaran matematika realistik disajikan atas dua pertimbangan yaitu memunculkan ragam aplikasi yang harus diantisipasi dalam proses pembelajaran dan (ii) kesesuaiannya sebagai hal yang berpengaruh dalam proses progressive mathematizing.

3. Self-developed models. Menurut Gravemeijer (2000) menjelaskan, berdasar prinsip ini saat mengerjakan masalah kontekstual siswa diberi kesempatan untuk mengembangkan model mereka sendiri yang berfungsi untuk

menjembatani jurang antara pengetahuan informal dan matematika formal. Pada tahap awal siswa mengembangkan model yang diakrabinya. Selanjutnya melalui generalisasi dan pemformalan akhirnya model tersebut menjadi sesuatu yang sungguh-sungguh ada (entity) yang dimiliki siswa.

Menurut Wijaya (2012) pembelajaran matematika realistik mempunyai beberapa karakteristik sebagai berikut.

1. Menggunakan konteks, artinya dalam pembelajaran matematika realistik lingkungan keseharian atau pengetahuan yang telah dimiliki siswa dapat dijadikan sebagai bagian materi belajar yang kontekstual bagi siswa.

2. Menggunakan model, artinya permasalahan atau ide dalam matematika dapat dinyatakan dalam bentuk model, baik model dari situasi nyata maupun model yang mengarah ke tingkat abstrak.

3. Menggunakan kontribusi siswa, artinya pemecahan masalah atau penemuan konsep didasarkan pada sumbangan gagasan siswa.

4. Interaktif, artinya aktivitas proses pembelajaran dibangun oleh interaksi siswa dengan siswa, siswa dengan guru, siswa dengan lingkungan dan sebagainya.

5. Integrasi, artinya topik-topik yang berbeda dapat diintegrasikan sehingga dapat memunculkan pemahaman tentang suatu konsep secara serentak. 
Nurhadi (Titikusumawati, 2009) pembelajaran melalui pendekatan kontekstual membantu pendidik dan siswa mengaitkan konten (isi) mata pelajaran dengan kehidupan seharihari siswa, hal ini tentunya akan memotivasi siswa membuat hubungan anatara pengetahuan yang ia dapatkan di kelas dalam kehidupan mereka sebagai anggota keluarga dan masyarakat. Siswa perlu melihat dan memahami hubungan antara matematika ketika mereka di dalam kelas dan di luar kelas, dan tidak melihatnya sebagai kesatuan-kesatuan yang terpisah. Dengan melihat matematika yang mereka peroleh di dalam kelas ternyata tidak jauh berbeda dan berhubungun dengan kehidupan sehari-hari akan mampu memotivasi.

Pembelajaran kontekstual ini dimulai dengan mengeksplor pengetahuan siswa, misalkan Tanya jawab yang terkait dengan dunia nyata, sehingga siswa merasakan manfaat dari materi yang diajarkan. Prinsip pembelajaran kontekstual adalah aktivitas siswa, siswa melakukan dan mengalamiya (Suyatno, 2009).

Uraian di atas dapat disimpulkan bahwa Mathematic In Context menekankan dinamis, sifat aktif matematika, cara memungkinkan siswa untuk memahami dunia mereka. Dalam kurikulum matematika tradisional, urutan pengajaran sering hasil dari generalisasi, untuk contoh spesifik, dan untuk aplikasi dalam konteks. Mathematic In Context membalikkan urutan ini, matematika berasal dari masalah nyata. Program ini memperkenalkan konsep-konsep dalam konteks yang realistis yang mendukung abstraksi matematika. Siswa diharapkan untuk mengeksplorasi hubungan matematika, mengembangkan dan menjelaskan penalaran mereka sendiri dan strategi untuk memecahkan masalah, penggunaan alat pemecahan masalah tepat, dan mendengarkan, memahami, dan nilai strategi masingmasing.

\section{Kemampuan Dan Keterampilan Berpikir Kreatif Matematis}

Tabriszi, at al (2011) berpikir kreatif adalah keterampilan yang menghasilkan penemuan dan pemikiran baru. Guilford (Kiswandono: 2000) mengatakan bahwa berpikir kreatif, sebagai kemampuan untuk melihat bermacam - macam penyelesaian terhadap suatu masalah, merupakan bentuk pemikiran yang sampai saat ini masih kurang mendapatkan perhatian. Oleh karena itu pemecahan masalah harus dipandang secara utuh sebagai "proses" dan melibatkannya ke dalam tahapan-tahapan proses berpikir kreatif, maka berpikir kreatif dapat dipandang sebagai suatu keseimbangan antara kemampuan berpikir divergen dan konvergen, artinya pertimbangan pengambilan keputusan cenderung membatasai diri hanya pada fakta yang ada saja, sedangkan imajinasi harus selalu melipatgandakan gagasan. 
Indikator pengukuran berpikir kreatif matematis sebagai berikut:

a. Aspek kefasihan/kelancaran yang meliputi kemampuan: menyelesaikan masalah dan memberikan banyak jawaban terhadap masalah tersebut, (2) memberikan banyak contoh atau pernyataan terkait konsep matematis tertentu.

b. Aspek keluwesan meliputi kemampuan: (1) menggunakan beragam strategi penyelesaian pemecahan masalah, memberikan beragam contoh atau pernyataan terkait konsep matematis tertentu.

c. Aspek kebaruan meliputi kemampuan: (1) menggunakan strategi bersifat baru, memberikan contoh pernyataan yang bersifat baru.

d. Aspek keterincian meliputi menjelaskan secara terperinci, runtut terhadap prosedur matematis.

Ciri-ciri perilaku yang ditemukan pada orang-orang yang memberikan sumbangan kreatif yang menonjol terhadap masyarakat digambarkan sebagai berikut: berani dalam pendirian/keyakinan, melit (ingin tahu), mandiri dalam berpikir dan mempertimbangkan, bersibuk diri terus menerus dengan kerjanya, intuitif, ulet dan bersedia menerima pendapat dari otoritas begitu saja. Ciri pribadi kreatif yang diperoleh dari kelompok pakar psikologi adalah sebagai berikut: imajinatif, mempunyai prakarsa, mempunyai minat yang luas, mandiri dalam berpikir, melit, senang berpetualang, penuh energi, percaya diri, bersedia mengambil resiko, dan berani dalam pendirian dan kemandirian. Sikap kreatif dioperasionalkan dalam dimensi berikut : (1) keterbukaan terhadap pengalaman baru; kelenturan dalam berpikir; kebebasan dalam ungkapan diri; (4) menghargai fantasi; (5) minat terhadap kegiatan kreatif; kepercayaan terhadap gagasan sendiri; dan (7) kemandirian dalam memberi pertimbangan (Filsaime, 2008).

Keterampilan berpikir kreatif adalah keterampilan kognitif untuk memunculkan dan mengembangkan gagasan baru, ide baru sebagai pengembangan dari ide yang telah lahir sebelumnya dan keterampilan untuk memecahkan masalah secara divergen (dari berbagai sudut pansang). Untuk memunculkan kreativitas dapat melalui berbagai pembelajaran, seperti pembelajaran kooperatif yang terdiri dari berbagai metode yang dapat dipakai.

\section{METODE PENELITIAN}

Penelitian ini merupakan penelitian kuantitatif, dengan metode pre eksperimen desain one group pretest postest. Sampel penelitian ini adalah siswa kelas IV SD $\mathrm{N}$ Kalijurang Tonjong.

Penelitian ini dilakukan selama 4 kali pertemuan. Pengumpulan data menggunakan metode tes berupa soal tes materi bangun datar untuk 
mengukur kemampuan berpikir kreatif, dan lembar observasi untuk mengukur keterampilan berpikir kreatif.

Teknik analisis yang digunakan yaitu uji banding rata-rata pretest dan posttest untuk melihat adanya peningkatan kemampuan berpikir kreatif dan uji banding yaitu membandingkan rata-rata nilai keterampilan berpikir kreatif dari pertemuan I, pertemuan II dan pertemuan III, untuk melihat peningkatan keterampilan berpikir kreatif.

\section{HASIL DAN PEMBAHASAN}

Hasil analisis data kemampuan berpikir kreatif siswa pada pembelajaran matematika dengan pendekatan Mathematic In Context dapat dilihat pada tabel berikut.

Tabel. 1. Analisis Deskriptif

Kemampuan Berpikir Kreatif

\begin{tabular}{cccc}
\hline Kelas & $\begin{array}{l}\text { Rata- } \\
\text { rata }\end{array}$ & Varian & $\begin{array}{c}\text { Standar } \\
\text { Deviasi }\end{array}$ \\
\hline Pretest & 78,88 & 94,987 & 9,74 \\
\hline Postest & 83,7 & 93,365 & 9,66 \\
\hline
\end{tabular}

Hasil menunjukkan 2,0626 . perhitungan $t_{\text {tabel }}=t_{(1-\alpha)\left(n_{1}+n_{2}-2\right)}$ pada $\alpha=5 \%$ adalah 1,667. Karena $t_{\text {hitung }}>t_{\text {tabel }}$ sehingga hipotesis $\mathrm{H}_{0}$ ditolak, artinya ada peningkatan yang signifikan ratarata kemampuan berpikir kritis pada pembelajaran matematika dengan pendekatan Mathematic In Context .
Hasil analisis data keterampilan berpikir kreatif siswa yang diamati melalui keterampilan prosesnya. Diperoleh bahwa ada peningkatan yang signifikan rata-rata keterampilan berpikir kreatif siswa pada pembelajaran matematika dengan pendekatan Mathematic In Context materi bangun datar dari beberapa pertemuan sesuai pada table berikut.

Tabel. 2. Rekapitulasi Rata-rata Keterampilan Berpikir Kreatif

\begin{tabular}{cccc}
\hline Pertemuan & I & II & III \\
\hline Rata-rata & 64 & 76 & 82 \\
\hline
\end{tabular}

Tingginya hasil posttest siswa pada pembelajaran matematika dengan pendekatan Mathematic In Context, disebabkan dalam proses pembelajaran peserta didik terlibat secara aktif. Selain itu, kebiasaan berpikir kreatif siswa Mathematic In Context, akan memudahkan siawa dalam memahami suatu topik keterkaitannya dengan topik lain, baik dalam pelajaran matematika maupun pelajaran lain atau dalam kehidupan sehari-hari. Mathematic In Context, dapat memberikan keleluasaan berpikir secara aktif dan mampu mengundang siswa untuk menjawab permasalahan melalui berbagai strategi sehingga memacu perkembangan matematikanya. Karena pembelajarannya tersebut dapat mengaitkan matematika dengan kontek apapun, dalam pembelajaran ini lebih mengaitkan matematika khususnya bangun datar dengan peristiwa atau benda-benda yang ditemui di lingkungan pada kehidupan 
bersosial siswa sehari-hari, dengan kontek nyata tersebut siswa akan lebih memahami dan mengembangkan keterampilan dan kemampuan berpikir kreatifnya.

\section{KESIMPULAN}

Berdasarkan hasil penelitian dapat disimpulkan sebagai berikut.

1. Terdapat peningkatan secara signifikan rata-rata kemampuan berpikir kreatif siswa pada pembelajaran matematika dengan pendekatan Mathematic In Context materi bangun datar

2. Terdapat peningkatan keterampilan berpikir kreatif pada pembelajaran matematika dengan pendekatan Mathematic In Context materi bangun datar.

\section{DAFTAR PUSTAKA}

Camarena. (2003). Models Mathematics in Context Sience. Journal Instituto Politecnico Nacional. Meksiko.

Filsaime, D., K. (2008). Menguak Rahasia Berpikir Kritis dan Kreatif. Jakarta: Prestasi Pustaka Publisher.

Gravemeijer, K. (2000). Symbolzing Modeling and Instructional design. Journal Freudental Institute.

Hamalik, O. (2008). Proses Belajar Mengajar. Jakarta: PT. Bumi Aksara. Kismandono, I. (2000). Berpikir Kreatif Suatu Pendekatan Menuju Berpikir Arsitektual. Universitas Kristen Petra.

Pehkonen, E. (1997). The State-of-Art in Mathematical Creativity.
ZDM Volume 29 (June 1997)

Number 3. Electronic Edition ISSN 1615-679X. http://www.emis.de/journals/ ZDM/zdm973a1.pdf.

Diunduh pada tanggal 10 Agustus 2012, pukul 20.23 WIB.

Suyatno. (2009). Model Pembelajaran

$$
\text { Inovatif. Surabaya : }
$$

Masmedia Buana Pustaka.

Tabrizi, at al. (2011). "Relationship between Creative Thinking and Anxiety Among Adolescent Boys and Girls in Tehran Iran”. International journal of Humanistic and Social Science. Vol 1 no 19

Titikusumawati, dkk. (2009). Pemerapan MiC Melalui Cycle Learning untuk Meningkatkan Pemahaman dan Aplikasi Konsep Matematika Siswa MA NW Pancor Lombok Timur NTB. Malakah Seminar Nasional Hasil PTK Terpilih.

Tumarang, K. (2000). Pembelajaran

Melalui Problem Solving untuk Menumbuhkan dan Meningkatkan Pemahaman Konsep Pengurangan Bagi iswa SD Kelas I. Tesis. Malang: PPs Universitas Negeri Malang.

Wijaya, A. (2012). Pendidikan Matematika Realistik Suatu Alternatif Pendekatan Pembelajaran Matematika. Yogyakarta: Graha Ilmu. 
